THE LOCKEAN THEORY OF RIGHTS 

STUDIES IN MORAL, POLITICAL,

AND LEGAL PHILOSOPHY

General Editor: Marshall Cohen

A list of titles in the series

appears at the back of the book 



\title{
THE LOCKEAN THEORY OF RIGHTS
}

\author{
A. John Simmons
}

PRINCETON UNIVERSITY PRESS

PRINCETON, NEW JERSEY 
Copyright $(1) 1992$ by Princeton University Press

Published by Princeton University Press, 41 William Street,

Princeton, New Jersey 08540

In the United Kingdom: Princeton University Press,

Chichester, West Sussex

All Rights Reserved

Library of Congress Cataloging-in-Publication Data

Simmons, A. John (Alan John), 1950-

The Lockean theory of rights / A. John Simmons.

p. cm.-(Studies in moral, political, and legal philosophy)

Includes bibliographical references and index.

ISBN 0-69-10378-17

1. Locke, John, 1632-1704-Contributions in political science.

2. Locke, John, 1632-1704-Contributions in human rights.

3. Locke, John, 1632-1704-Contributions in natural law.

I. Title. II. Series.

JC153.L87S56 1992

$323^{\prime} .01-\mathrm{dc} 20$

$91-36773$

This book has been composed in Linotron Palatino

Princeton University Press books are printed on acid-free paper and meet the guidelines for permanence and durability of the Committee on Production Guidelines for Book Longevity of the Council on Library Resources

Printed in the United States of America

$\begin{array}{lllllllll}3 & 5 & 7 & 9 & 10 & 8 & 6 & 4 & 2\end{array}$ 